\title{
La artroscopia en el daño interno de la ATM: resultados clínicos de un estudio prospectivo
}

\section{Arthroscopy for the internal derangement of TMJ: clinical outcome from a prospective evaluation}

\author{
F.J. Avellá Vecino', C.I. Salazar Fernández², S. Gallana Álvarez', A. Rollón Mayordomo², \\ F. Mayorga Jiménez², J.M. Pérez Sánchez ${ }^{3}$
}

Resumen: Objetivos. El síndrome disfunción témporomandibular (SDTM) es un cuadro clínico multifactorial, ante el cual se preconiza un tratamiento escalonado en función de su gravedad. Nuestro objetivo es valorar la eficacia del tratamiento artroscópico mediante lisis y lavado en un grupo homogéneo de pacientes diagnosticados de SDTM según parámetros clínicoradiológicos. Diseño del estudio. Realizamos un estudio prospectivo de 22 articulaciones (13 pacientes), con el diagnóstico de daño articular interno, tratadas mediante lisis y lavado artroscópico entre febrero de 1996 y abril de 2001. Antes y después del tratamiento, así como durante el seguimiento (rango: 12-63 meses, media: 27 meses) se valoraron el dolor, MAO, movilidad en protrusiva y laterotrusiva, ruidos, y RM. Resultados. Realizamos un estudio estadístico descriptivo de las variables continuas, comparando los valores pre y posquirúrgicos con el test de Wilcoxon y Mc Nemar demostrando mejoría significativa a lo largo del seguimiento. Con el test de la U de Man Whitney se comparó el dolor y la MAO entre los estadios tempranos y tardíos de la enfermedad, siendo la mejoría significativamente mayor para los estadios tempranos. Los hallazgos radiológicos de la RM al año mejoraron en el $27 \%$ (estadios II-III de Wilkes). Según los criterios de Murakami obtuvimos una tasa de éxito del $23 \%$, y resultado satisfactorio en el $77 \%$. Conclusiones. El lavado y lisis articular es una técnica útil y efectiva para el SDTM, tanto en los estadíos tempranos como tardíos de la enfermedad, mejorando significativamente el dolor, MAO, protrusión, laterotrusión y los ruidos articulares. La mejoría de la apertura interincisal con la lisis y lavado artrocópico es mayor en los estadíos tempranos de la enfermedad.

Palabras clave: Cirugía Artroscópica; Daño Articular Interno; Articulación Témporomandibular; Lisis y Lavado.

\footnotetext{
1 Médico Residente.

2 Médico Adjunto.

3 Jefe del Servicio. Servicio de Cirugía Máxilofacial y Estomatología del Hospital Universitario Virgen Macarena, Sevilla, España.
}

\begin{abstract}
Objective. The tempormandibular joint dysfunction syndrome (TMJD) syndrome has a multifactorial etiology. Patients are considered operative candidates when nonsurgical therapy fails to adequately control symptoms. Our objective is to demonstrate the efficacy of arthroscopic lysis and lavage treatment for a homogeneous group of patients diagnosed of TMJD according to clinical-radiographic parameters. Design. This article reports a prospective study of 22 articulations (13 patients) diagnosed of internal derangement of TMJ and treated with lysis and lavage arthroscopy from February 1996 to April 2001. Before and after treatment as well as during the follow-up (range: 12-63 months, mean: 27 months), the following parameters were considered: pain, $M I O$, protrusive and laterotrusive mobility, noises, and MRI. Results. We performed a descriptive statistical study of continuous variables, comparing the pre-and postsurgery values with Wilcoxon and Mc Nemar tests, demonstrating a significant improvement during follow-up. Mann Whitney U Test was used for comparing pain and MIO between early and advanced stages, demonstrating a significantly greater improvement for early stages. The MRI results at one year of follow-up supports improvement in 27\% (II-III Wilkes stages). According to Murakami criteria we obtained $23 \%$ excellent outcome, and 77\% favorable outcome. Conclusions. Joint lysis and lavage is a useful and effectiveness method for treatment of internal derangement for early stages as well as for late stages, improving pain, MIO, protrusive and laterotrusive movements, and noises significantly. The improvement of MIO with arthroscopic lysis and lavage is greater for early stages.
\end{abstract}

Key words: Arthroscopic surgery; Internal derangement; Temporomandibular joint, Lysis and lavage.

Correspondencia:

F.J. Avellá Vecino

C/ José Rodríguez Guerrero 9

41009 Madrid, España.

e-mail: javiavella@terra.es 


\section{Introducción}

El Síndrome de disfunción témporomandibular (SDTM), es una cuadro clínico multifactorial, ante el cual se preconiza un tratamiento escalonado en función de su gravedad. ${ }^{1}$ A pesar de haberse utilizado diversas técnicas para el tratamiento del SDTM, ${ }^{2}$ ninguna ha gozado de plena aceptación, lo cual refleja el desconocimiento que rodea a este cuadro sindrómico en cuanto a etiología, patología e historia natural. Los estudios sobre el tratamiento quirúrgico de esta patología, ${ }^{3}$ han demostrado mejoría en la apertura de boca y del dolor, sin embargo están limitados por los defectos frecuentemente asociados a los estudios clínicos retrospectivos: definición pobre del grupo de enfermos, falta de grupo control, sesgo del observador, pérdidas de pacientes en el seguimiento, etc.

Nuestro objetivo es demostrar la eficacia clínica de la lisis y lavado articular mediante un estudio prospectivo de pacientes con daño interno articular tratados mediante artroscopia de la ATM en un grupo homogéneo.

\section{Material y método}

Se realiza un estudio de seguimiento prospectivo desde Febrero de 1996 hasta Abril del 2001, con objeto de evaluar los resultados clínico-radiológicos a largo plazo tras la cirugía artroscópica (lisis y lavado articular) de 22 articulaciones (13 pacientes) con SDTM diagnosticados y tratados en el H.U. Virgen Macarena de Sevilla, España. El rango de seguimiento oscila entre un mínimo de 12 meses y un máximo de 63 meses, con una media de 27 meses y una mediana de 26 .

Los criterios de inclusión para la cirugía artroscópica fueron los establecidos por la Asociación Americana de Cirugía de la ATM: ${ }^{4}$

- SDTM de una o ambas ATM, diagnosticados clínicamente y confirmados mediante RM.

- Sintomatología refractaria al tratamiento conservador mantenido durante 6 meses (AINES + relajantes musculares + analgésicos, fisioterapia, férulas de miorelajación y rehabilitación oclusal).

Los pacientes completaron, antes del tratamiento quirúrgico, un cuestionario clínico que incluía datos demográficos, sintomatología clínica, duración de los síntomas, historia de los ruidos articulares, alteración del patrón de movimientos mandibulares, existencia de parafunciones, tratamientos ortodóncicos recientes, antecedentes de traumatismos faciales y patología articular. El dolor articular se midió mediante una escala analógica visual (0-10).

La exploración clínica incluyó: máxima apertura interincisal (MAO), máxima protrusión y máxima laterotrusión mandibular (expresadas en $\mathrm{mm}$ ), medidas mediante regla curva milimétrica. Se realizó la palpación y auscultación de la ATM para valorar la presencia de ruidos articulares (chasquido, crepitación) así como el momento de apertura-cierre oral en que ocurrían. Igualmente, se exploraron los músculos masticatorios (dolor, contractura) y la oclusión de cada paciente (clase de Angle, guía canina, línea media, estabilidad oclusal, ausencia de dientes).

A todos los pacientes se les realizó una ortopantomografía, radiografía lateral de cara en proyección de Schüller con boca cerrada y en máxima apertura y RM de la ATM. En la RM se obtuvieron imáge-

\section{Introduction}

The temporomandibular dysfunction syndrome (TMJD) is a multifactorial clinical picture for which a step by step treatment based on seriousness is advocated. In spite of having used varied techniques for the treatment of TMJD, ${ }^{2}$ none has had full acceptance, which reflects the lack of knowledge surrounding this syndromic picture in regards to etiology, pathology and natural history. The studies on the surgical treatment 3 of this disease have demonstrated improvement in mouth opening and pain, however, they are limited due to the defects that are frequently associated to retrospective clinical studies: poor definition of the patient group, lack of control group, observer bias, loss of patients to follow-up, etc.

Our objective is to demonstrate the clinical efficacy of joint lysis and lavage by a prospective study of patients with internal joint derangement treated by arthroscopy of the temporomandibular joint (TMJ) in a homogeneous group.

\section{Material and method}

A prospective follow-up study was performed from February 1996 to April 2001, in order to assess the long term clinical-radiological results after arthroscopic surgery (joint lysis and lavage) of 22 joints (13 patients) with diagnosed TMJD treated in the University Hospital Virgen Macarena of Seville. The follow-up range varied from a minimum of 12 months to a maximum of 63 months, with a mean of 27 months and a median of 26 months.

Inclusion criteria for arthroscopic surgery were those established by the American Association of Surgery of the $T M]: 4$

- TMJD of one or both TMJ, clinically diagnosed and verified by MRI.

- Symptoms refractory to conservative treatment maintained for 6 months (NSAIDs + muscle relaxants + analgesics, physiotherapy, myorelaxation splints and occlusal rehabilitation),

The patients filled out a clinical questionnaire before surgical treatment that included demographic data, clinical symptoms, symptom duration, history of articular noises, alteration of mandibular movement pattern, existence of parafunctions, recent orthodontic treatments, background of facial traumatisms and articular pathology. The joint pain was measured by a visual analogue scale (0-10).

The clinical examination included: maximum intraincisal opening (MIO), maximum protrusion and maximum mandibular laterotrusion (expressed in $\mathrm{mm}$ ), measurements by millimetric curve ruler. Palpation and auscultation of the TMJ were performed to assess the presence of articular noises (snapping sound, crackling sounds), as well as the moment of oral opening-closure in which they occur. Furthermore the chewing muscles (pain, contracture) and 
Tabla 1. Síntomas preoperatorios.

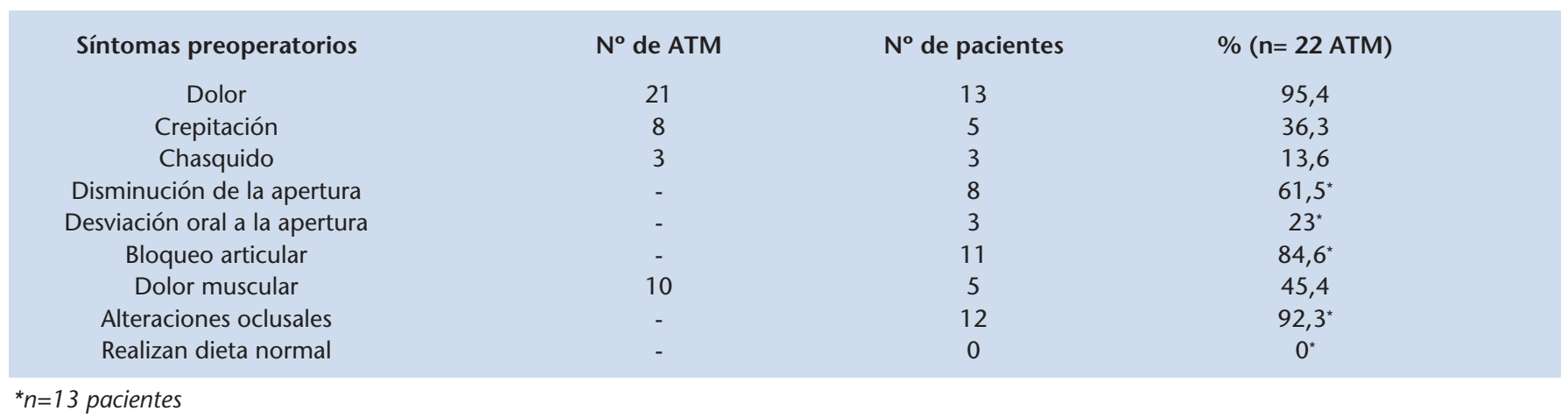

Table 1. Preoparative symptoms.

$\begin{array}{cccc}\text { Preoperative symptoms } & \text { No. of TMJ } & \text { No. of patients } & \text { \% (n=22 TMJ) } \\ \text { Pain } & 21 & 13 & 95.4 \\ \text { Crackling sound } & 8 & 5 & 36.3 \\ \text { Snapping sound } & 3 & 3 & 13.6 \\ \text { Decrease of opening } & - & 8 & 61.5^{*} \\ \text { Oral deviation of opening } & - & 3 & 23^{*} \\ \text { Articular locking } & - & 11 & 84.6^{*} \\ \text { Muscle pain } & -10 & 12 & 45.4 \\ \text { Occlusal disorders } & - & 0 & 92.3^{*} \\ \text { Having a normal diet } & & & 0^{*} \\ { }^{*} n=13 \text { patients } & & \end{array}$

nes en el plano sagital (perpendiculares al eje mayor del cóndilo mandibular) y coronal, en 4 aperturas orales progresivas. Los parámetros de la RM fueron tiempo de recepción $=200 \mathrm{~m}$, tiempo de eco = $15 \mathrm{~m}$, ángulo de giro de $45^{\circ}$ y campo de visión de $170 \mathrm{~mm}$. El espesor de los cortes fue de $3 \mathrm{~mm}$. Se estudió la posición del menisco articular en relación a la fosa glenoidea y cóndilo mandibular, la morfología del menisco (clasificación de De Leew, ${ }^{5}$ bicóncavo, biplano, biconvexo, doblado y amorfo), del cóndilo mandibular y de la fosa glenoidea. Al año del tratamiento artroscópico se repitió de nuevo a todos los pacientes un estudio de RM con las mismas caracteristicas técnicas descritas, que fue realizado y valorado por los mismos facultativos que valoraron la RM inicial.

Técnica quirúrgica: Todas los pacientes fueron intervenidos bajo anestesia general por el mismo cirujano y con el mismo instrumental. Se realizaron artroscopias mediante abordaje póstero-lateral de la articulación con una doble vía (artroscopio, y via de lavado); se usó un artroscopio TMJ mini-scope set (Stryker ${ }^{\circledR}$ ) con una angulación de $30^{\circ}$. Todas las articulaciones se trataron mediante la lisis de adherencias con un obturador romo realizando movimientos anteroposteriores y lateromediales, y lavado de la cavidad articular con 200-500 ml de suero Ringer lactato así como manipulación mandibular. En los casos de sinovitis se administró $3 \mathrm{mg}$ de betametasona intra-articular. En todos los casos se realizó profilaxis antibiótica con Augmentine $2 \mathrm{~g}$ IV.

El tratamiento postoperatorio consistió en dieta líquida/blanda durante 1 mes, AINES + Analgésicos + relajantes musculares durante occlusion of each patient (Angle class, canine guidelines, middle line, occlusion stability, lack of teeth) were examined.

All the patients underwent a panoramic $X$-ray, lateral $X$ ray of the face in Schuller project with closed mouth and in maximum opening and MRI of the TMJ. In the MRI, images were obtained in the sagittal (perpendicular to the major axis of the mandibular condyle) and coronal plane, in 4 progressive oral openings. The parameters of the MRI were reception time $=200 \mathrm{~ms}$, echo time $=15 \mathrm{~ms}$, rotation angle of $45^{\circ}$ and vision field of $170 \mathrm{~mm}$. The cut thickness was $3 \mathrm{~mm}$. The articular meniscus position was studied in relationship with the glenoid fossa and mandibular condyle, morphology of meniscus (Biconcave, biplanar, biconvex, folded and amorphous De Leew classification)5 of the mandibular condyle and of the glenoid fossa. At one year of arthroscopic treatment, a MRI study was repeated in all the patients with the same technical characteristics described and was performed and assessed by the same physicians who had assessed the initial MRI.

Surgical technique: All the patients were operated under general anesthesia by the same surgeon and with the same instrumental. Arthroscopies were performed by posterolateral approach of the articulation with a double pathway (arthroscopy and lavage pathway); a TMJ mini-scope set 
Tabla 2. Estadios de Wilkes.

\begin{tabular}{|c|c|c|c|}
\hline Estadios de Wilkes & $N^{\circ}$ de articulaciones & Hallazgos radiológicos & RM \\
\hline III & $4(15 \%)$ & N/rectificación/ Ø & DAI \\
\hline V & $5(19 \%)$ & artrosis & $\mathrm{DAI}+\mathrm{ARTÇ}$ \\
\hline
\end{tabular}

N: normal; Ø: disminución del espacio articular; DAR: desplazamiento anterior reducible; DAl: desplazamiento anterior irreducible; *: derrame art., alt. degenerativas tempranas; ARTÇ: signos artrósicos (perforación del lig. posterior); $n=22$ articulaciones

Table 2. Wilkes stages.

$\begin{array}{cc}\text { Wilkes Stages } & \text { No. of articulations } \\ \text { II } & 5(19 \%) \\ \text { III } & 4(15 \%) \\ \text { IV } & 8(31 \%) \\ \text { V } & 5(19 \%)\end{array}$

$\begin{array}{cc}\text { X-ray findings } & \text { MRI } \\ N & \text { ARD } \\ \mathrm{N} / \text { rectification/ } \varnothing & \text { AID } \\ \text { rectification/ } \varnothing \text { /arthrosis } & \text { AID* } \\ \text { arthrosis } & \text { AID + ARTÇ }\end{array}$

$N$ : normal; Ø: decrease of articular space; ARD: anterior reducible displacement; AID: anterior irreducible displacement; *: art. effusion, early degenerative alt., ARTÇ: arthrosic signs (perforation of posterior lig); $n=22$ articulations.

10 días, férula de miorelajación nocturna durante 1 mes y fisioterapia durante 3 meses.

Todos los pacientes fueron examinados por el mismo cirujano, que realizó la cirugía artroscópica, a la semana, al mes, 3, 6, y 12 meses tras la artroscopia y posteriormente cada 6 meses. Se valoraron las siguientes variables: dolor articular y ruidos articulares $(n=22$ articulaciones), máxima apertura interincisal, máxima protrusión y laterotrusión mandibular, dieta tolerada por el paciente (capacidad para realizar la dieta habitual y masticar carne), uso de la férula de miorelajación ( $n=$ 13 pacientes), hallazgos artroscópicos, complicaciones de la técnica y el consumo de recursos de la misma.

Se realizó un estudio estadístico descriptivo de las variables continuas (medias y desviaciones estándar). El estudio comparativo de las variables pre y postquirúrgicas se realizó mediante los test de Wilcoxon y McNemar. Se aplicó el test de la U de Mann-Whitney para comparar el dolor y los parámetros de movilidad mandibular entre los estadios tempranos (II-III) y los estadios tardíos (IV-V) de la enfermedad en cada tiempo (prequirúrgico y al año del seguimiento). Definimos la significación estadística para un valor de $p$ menor o igual a 0,05.

\section{Resultados}

Se trataron 22 articulaciones (13 pacientes) con una edad media de 31 años (19-65 años). Presentaron algún antecedente predisponente del SDTM en el $92 \%$ de los casos. Como puede verse en la tabla 1, 21 articulaciones fueron dolorosas, siendo el dolor el síntoma principal en 10 pacientes (76\%).

Los datos recogidos en el estudio radiográfico y RM, y la distribución por estadios según la clasificación de Wilkes, ${ }^{6}$ se muestran en la tabla 2. Así, en el estadio II encontramos que la radiología fue anodina mientras que la resonancia demostraba un desplazamiento discal anterior reductible. En el estadio III se detectó la rectificación de la ver- arthroscopy (Stryker $\left.{ }^{\circledR}\right)$ with a $30^{\circ}$ angle was used. All the joints were treated by lysis of adhesions with a blunt obturator, performing anteroposterior and lateromedial movements, and lavage of the articular cavity with $200-500 \mathrm{ml}$ of Ringer lactate solution as well as mandibular manipulation. In the cases of synovitis, $3 \mathrm{mg}$ of intraarticlar betametasone were administered. In all the cases, antibiotic prophylaxis was performed with $2 \mathrm{~g}$ i.v. Augmentine.

The postoperative treatment consisted in liquid/soft diet for 1 month, NSAIDs + analgesics + muscle relaxants for 10 days, nighttime myorelaxation splint for 1 month and physiotherapy for 3 months.

All the patients were examined by the same surgeon, who performed the arthroscopic surgery, at one week, one month, 3, 6 and 12 months of the arthroscopy and then every 6 months. The following variables were assessed: articular pain and articular noises ( $n=22$ articulations), maximum interincisal opening, maximum protrusion and mandibular laterotrusion, diet tolerated by the patient (capacity to receive the usual diet and chew meat), use of myorelaxation splint ( $n=13$ patients), arthroscopic findings, technique complications and consumption of its resources.

A descriptive statistical study was performed on the continuous variables (means and standard deviations). The comparative study of the pre-and postsurgical variables was performed with The Wilcoxon and McNemar tests. The Mann-Whitney U test was administered to compare pain and the mandibular mobility parameters between the early (II-III) and late stages (IV-V) of the disease in each time (presurgical and at one year of follow-up). We define statistical significance for a $p$ value less than or equal to 0.05 . 
tiente posterior del cóndilo y/o disminución del espacio articular junto con desplazamiento meniscal irreductible en la RM. En el estadio IV aparecen derrame articular y signos tempranos de degeneración articular en la RM, así como signos de artrosis en la radiología. Por último en el estadio $\mathrm{V}$, a todo lo anterior se añadió la perforación del ligamento posterior como hallazgo de la resonancia.

Tras la artroscopia, el dolor mejora en el $80 \%$ de los casos (17 articulaciones), así como los parámetros de MAO, protrusiva, y laterotrusiva derecha e izquierda, mejoraron en un 100, 92, 84, y $92 \%$ respectivamente. En el $63 \%$ de los casos desaparecieron los ruidos, mejorando en 7 articulaciones. La evolución de estas variables a lo largo del tiempo se aprecia en las figuras 1 a 5 .

El estudio comparativo pre y postquirúrgico a los 12 meses de seguimiento de los valores de las variables dolor, MAO, protrusión, laterotrusión, ruidos articulares, y dieta tolerada, demuestra una mejoría en todas estas variables con significación estadística (Tabla 3). Estos datos se mantuvieron al final del seguimiento del estudio, al igual que por estadios (Tabla 4). La mejoría en la MAO y el dolor fue significativamente mayor para los estadios II-III que para los estadios avanzados de la enfermedad. Precisaron férula de miorelajación postartroscopia el 38\% (5 pacientes).

Los hallazgos radiológicos de la RM realizada al año de la artroscopia mejoraron (irreducible a reducible, de reducible a normal) en el $27 \%$ de las articulaciones afectas $(n=6)$, tratándose de estadios II - III de Wilkes. En el resto de los casos, la RM permaneció similar sin revelar cambios progresivos severos.

Todos los pacientes presentaron mejoría en algunas o todas las variables analizadas. Siguiendo los criterios de Murakami: ${ }^{7}$ Consideraremos resultados excelentes cuando no exista dolor, la MAO sea de 40-50 mm, los movimientos protrusivo y de laterotrusión sean mayor o igual a 6 $\mathrm{mm}$, la ausencia de ruidos, que el paciente pueda realizar una dieta normal y mejora en el estudio de la RM postartroscopia. Consideraremos resultados satisfactorios una MAO de 3035 mm, dolor ligero (1-3 según la escala analógica visual), restricción dietética mínima y los hallazgos en la RM postartroscopia similares al estudio prequirúrgico. Según estos criterios, hemos tenido una tasa de

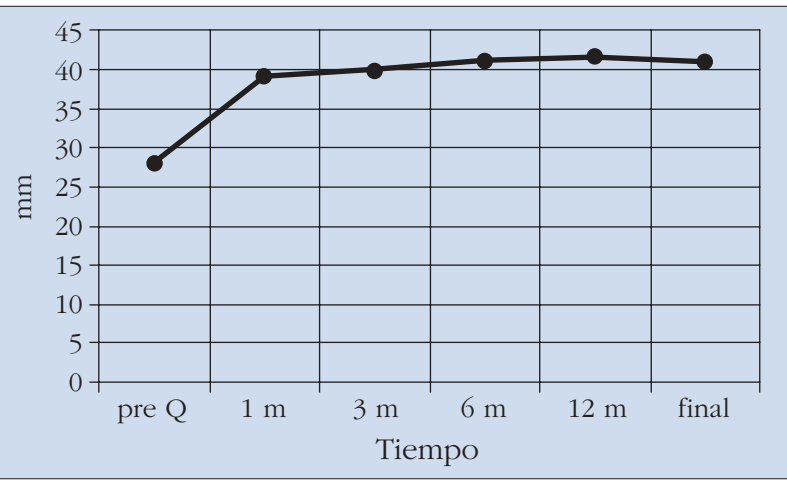

Figura 1. Representación gráfica de la evolución de la máxima apertura oral a lo largo del estudio.

Figure 1. Graphic representation of the evolution of the maximum oral opening during the study.

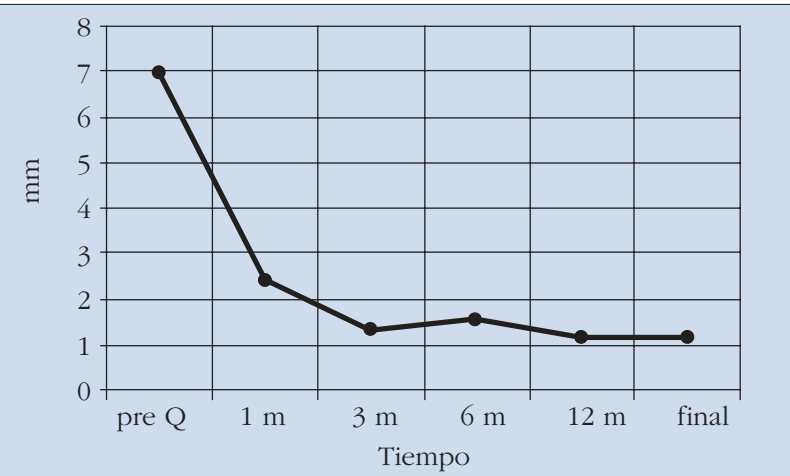

Figura 2. Representación gráfica de la evolución del dolor a lo largo del estudio.

Figure 2. Graphic representation of the evolution of pain during the study.

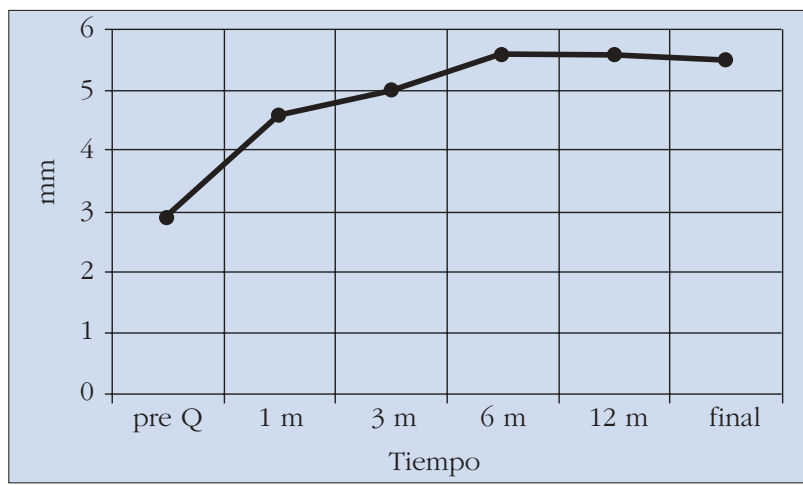

Figura 3. Representación gráfica de la evolución de la movilidad en protrusiva a lo largo del estudio.

Figure 3. Graphic representation of the evolution of the mobility in protusive during the study.
Results

A total of 22 articulations (13 patients) with a mean age of 31 years (19-65 years) were treated. They presented some predisposing background of TMID in $92 \%$ of the cases. As can be seen in Table 1, 21 articulations were painful, the main symptom being pain in 10 patients (76\%).

The data collected in the X-ray study and $M R I$, and the distribution by stages according to Wilkes classification6 are shown in Table 2. Thus, in stage II, we found that the X-ray was harmless while the resonance demonstrated an anterior reducible disk displacement. In stage III, the rectification of the posterior slope of the condyle and/or decrease of the articular space together with the irreducible meniscus displacement was detected in the MRI. In stage IV, articular effusion and early signs of articular degeneration appear in the MRI as well as signs of arthrosis in the X-ray. Finally, in stage $V$, the perforation of the posterior ligament is added to all the above as a finding of the resonance.

After the arthros. copy, the pain improved in $80 \%$ of the cases (17 joints) and the MIO, protrusive and right and left laterotrusive parameters improved in $100 \%, 92 \%, 84 \%$, and $92 \%$ respectively. In $63 \%$ of the cases, the noises disappeared, improving in 7 articulations. The evolution of these variables over time appears in Figures 1 to 5 . 
éxito (excelente) del 23\% (3 pacientes) y resultados satisfactorios del $77 \%$ (10 pacientes), siendo en el $50 \%$ de estos casos (5 pacientes) estadios avanzados de la enfermedad.

No se detectó ninguna complicación postquirúrgica. El consumo de recursos de la técnica, medido por estancia hospitalaria, tiempo quirúrgico, infiltración con CORT fue: estancia media hospitalaria de 2,4 días (2-3 días), tiempo quirúrgico medio de 1,30 h (60-115 minutos), el 61\% de los pacientes precisaron infiltración articular con corticoides por sinovitis.

\section{Discusión}

Desde que Onishi, 8 realizara en Japón por primera vez una artroscopia en 1975, esta técnica se ha desarrollado ampliamente en Estados Unidos y Europa, difundiéndose en la literatura el éxito de la misma.

En 1990 Perrott y cols. ${ }^{9}$ en un estudio prospectivo de 76 articulaciones tratadas mediante lisis y lavado, obtiene un incremento de la media de la MAO de 29,91 \pm $10,1 \mathrm{~mm}$ a $37,93 \pm 10,52 \mathrm{~mm}$, siendo estadísticamente significativo, así como disminución del dolor medido mediante escala visual analógica y categorizado (ninguno, medio, moderado y severo), con un segui-

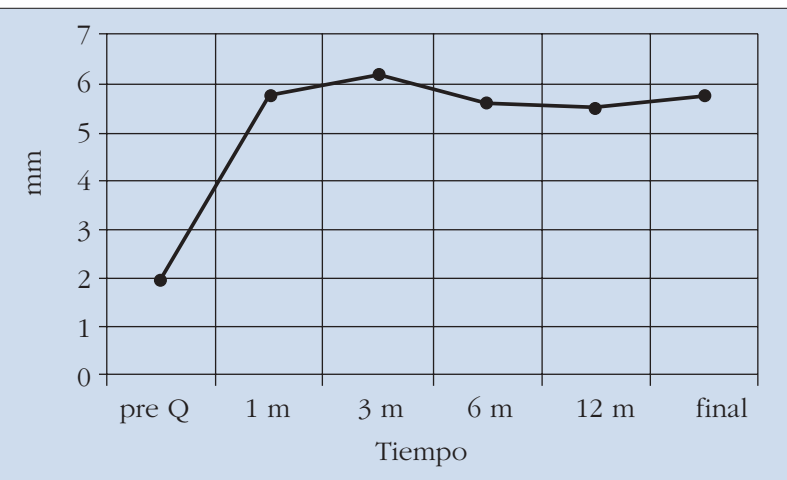

Figura 4. Representación gráfica de la evolución de la movilidad en laterotrusiva a lo largo del estudio.

Figure 4. Graphic representation of the evolution of the mobility in laterotrusive during the study.

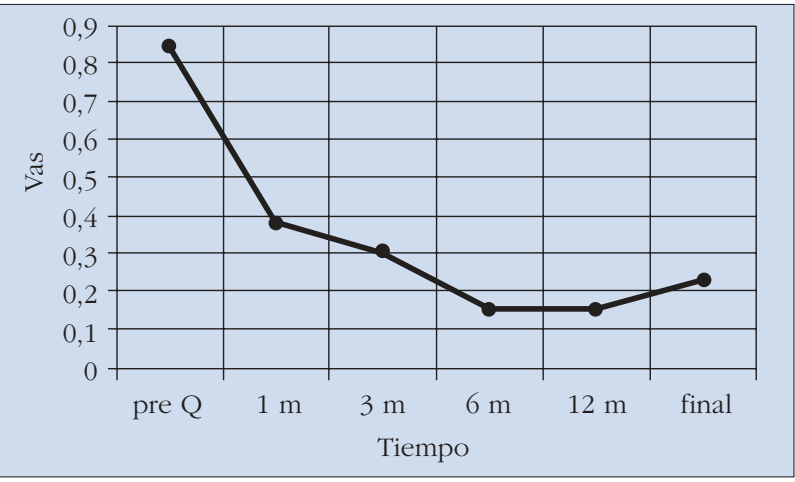

Figura 5. Representación gráfica de la evolución de los ruidos a lo largo del estudio.

Figure 5. Graphic representation of the evolution of noises during the study. miento medio de 12,56 $\pm 2,87$ meses para sólo 34 articulaciones del total. La comparación de las RM postartroscopia (entre 1 y 17 meses) con las imágenes previas, no arroja diferencias en cuanto a posición discal en 25 de 29 articulaciones estudiadas. En 1991 Clark y cols. ${ }^{10}$ realizan un estudio prospectivo de seguimiento de dos años postartroscopia de 22 articulaciones (18 sujetos) con daño interno de la ATM, obteniendo una disminución del dolor del 57\%, y un incremento de la media de la MAO de 13 mm, ambos estadísticamente significativos. En 1996 Murakami y cols. ${ }^{7}$ publican un estudio con un seguimiento medio de 50 meses (de 3 a 5 años) tras la cirugía artroscópica de 24 ATMs (mujeres) con daño articular interno en estadio $V$ de Wilkes, practicando liberación anterolateral capsular mediante electrocauterización y valorando la MAO, dolor y la disfunción articular mediante una VAS pre y postoperatoriamente, así como la presencia de chasquido a la auscultación y palpación. Obtienen diferencias estadísticamente significativas entre los valores de media pre y postquirúrgicas, con una media de MAO de 33 a 38,8 respectivamente, y disminución del dolor de 7 a 1,3.

En nuestro estudio evaluamos los resultados clínico-radiológicos tras la aplicación de lisis y lavado mediante artroscopia en los pacientes diagnosticados de SDTM. Siendo conscientes de los inconvenientes de un tamaño muestral no amplio, realizamos un estudio prospectivo con un seguimiento medio de 27 meses (rango: 12 a 63 meses)
The pre- and postsurgical comparative study at 12 months of follow-up of the values of pain, MIO, protrusion, laterotrusion, articular noises and diet tolerated variables shows improvement in all these variables with statistical significance (Table 3). These data were maintained at the end of the study followup, as well as by stages (Table 4). The improvement in the MIO and pain was significantly greater for stages II-III than for the advanced stages of the disease. A total of 38\% (5 patients) required post-arthroscopy myorelaxation splint.

The X-ray findings of the MRI performed at one year of the arthroscopy improved (irreducible to reducible, from reducible to normal) in $27 \%$ of the articulations affects $(n=6)$, these being Wilkes Stages II - III. In the rest of the cases, the MRI remained similar without revealing severe progressive changes.

All the patients presented improvement in some or all the variables analyzed. Following the Murakami criteria7: we consider excellent results when there is no pain, the MIO is $40-50 \mathrm{~mm}$, the protrusive and laterotrusion movements are greater or equal to $6 \mathrm{~mm}$, there is absence of noises, the patient can have a normal diet and there is improvement in the post-arthroscopy MRI study. We consider satisfactory results to be a MIO of 30-35 mm, mild pain (1-3 according o the visual analogue scale), minimum dietary restriction and findings in the post-arthroscopy MRI similar to the presurgical study. According to these criteria, we have had a success rate (excellent) of 23\% (3 patients) and satisfactory results of $77 \%$ (10 patients), there being advanced stages of the disease in $50 \%$ of these cases (5 patients).

No postsurgical complication was detected. The use of technique resources, measured by hospital stay, surgical time, CORT infiltration was: mean hospital stay of 2.4 days (2-3 days), mean surgical time of $1.30 \mathrm{~h}$ (60-115 minutes) $61 \%$ of the patients required articular infiltration with corticosteroids due to synovitis. 
Tabla 3. Variables clínicas.

$\begin{array}{lccc} & \text { PreAC } & \text { PostAC } & \text { P value } \\ \text { Dolor } & 6,9 \pm 1,8 & 1,1 \pm 2,8 & 0,002 \\ \text { MAO } & 27,9 \pm 8,1 & 41,6 \pm 8,7 & 0,001 \\ \text { Protusión } & 2,7 \pm 1,4 & 5,5 \pm 2,1 & 0,003 \\ \text { Laterotrusión D } & 2,9 \pm 2,2 & 5,3 \pm 1,9 & 0,009 \\ \text { Laterotrusión I } & 1,9 \pm 2,1 & 5,5 \pm 2,4 & 0,010 \\ \text { Presencia de ruidos } & 50 \% & 18 \% & 0,016 \\ \text { Toleran dieta normal } & 0 \% & 77 \% & 0,004\end{array}$

Los datos muestran la media con la desviación estándar.

* Todas las variables se compararon con el test de Wilcoxon menos los ruidos y la dieta que fueron comparados mediante el test de McNemar.

Tabla 4. Estadios.

\begin{tabular}{lccccc} 
& \multicolumn{2}{c}{ Estadios II-III } & \multicolumn{2}{c}{ Estadios IV-V } & P \\
& PreAC & PostAC & PreAC & PostAC & \\
Dolor & 6,4 & 1,6 & 7,2 & 1 & 0,01 \\
MAO & 27,6 & 46,2 & 28,1 & 38 & 0,01 \\
Protrusión & 3 & 6,6 & 2,8 & 4,8 & 0,02 \\
Laterotrusión & 3,2 & 5,8 & 2,7 & 5,4 & 0,04 \\
Ruídos & $77 \%$ & $11 \%$ & $38 \%$ & $23 \%$ & \\
Media & & & & & \\
\hline
\end{tabular}

Table 3. Clinical data.

$\begin{array}{lccc} & \text { PreAC } & \text { PostAC } & \text { P value } \\ \text { Dolor } & 6.9 \pm 1.8 & 1.1 \pm 2.8 & 0.002 \\ \text { MAO } & 27.9 \pm 8.1 & 41.6 \pm 8.7 & 0.001 \\ \text { Protrusion } & 2.7 \pm 1.4 & 5.5 \pm 2.1 & 0.003 \\ \text { Laterotrusión D } & 2.9 \pm 2.2 & 5.3 \pm 1.9 & 0.009 \\ \text { Laterotrusión I } & 1.9 \pm 2.1 & 5.5 \pm 2.4 & 0.010 \\ \text { Presence of noise } & 50 \% & 18 \% & 0.016 \\ \text { Tolerate normal diet } & 0 \% & 77 \% & 0.0004\end{array}$

The data show the mean with standard deviation.

* All the variables were compared with the Wilcoxon test except noises and diet that were compared with the McNemar test

Table 4. Stages.

\begin{tabular}{lccccc} 
& \multicolumn{2}{c}{ Stages II-III } & \multicolumn{2}{c}{ Stages IV-V } & P \\
& PreAC & PostAC & PreAC & PostAC & \\
Pain & 6.4 & 1.6 & 7.2 & 1 & 0.01 \\
MIO & 27.6 & 46.2 & 28.1 & 38 & 0.01 \\
Protrusion & 3 & 6.6 & 2.8 & 4.8 & 0.02 \\
Laterotrusion & 3.2 & 5.8 & 2.7 & 5.4 & 0.04 \\
Ruídos & $77 \%$ & $11 \%$ & $38 \%$ & $23 \%$ & \\
Mean & & & & & \\
\hline
\end{tabular}

sin pérdidas de datos durante el mismo. Al igual que en los estudios anteriormente citados, demostramos la utilidad de la artroscopia como tratamiento del daño articular interno de la ATM mediante lisis y lavado, tras obtener una mejoría estadísticamente significativa del dolor, $\mathrm{MAO}$, protrusión, laterotrusión derecha e izquierda, y chasquidos en el $80,100,92,84,92$ y $63 \%$ de los pacientes respectivamente, pudiendo realizar una dieta normal el $77 \%$ de los pacientes y precisando férula de miorelajación postartroscopia sólo el 38\%. Además, esta mejoría de las variables se da tanto en los estadios tempranos como en avanzados del SDTM, manteniéndose a lo largo del período de seguimiento. No obstante, la mejoría de la MAO es significativamente mayor cuando la técnica es aplicada en los estadios tempranos de la enfermedad.

Coincidimos con los resultados presentados por Moses y cols, ${ }^{11}$ en un estudio prospectivo de 152 articulaciones con desplazamiento discal anterior tratadas mediante lisis y lavado artroscópico, con un seguimiento medio de 19 meses, donde obtienen una mejoría de la movilidad discal en el $80 \%$ de los pacientes, aunque con persistencia del desplazamiento discal anterior en el $92 \%$ de los mismos detectado por RM. En nuestro estudio también llevamos a cabo un análisis de los hallazgos radiológicos pre y postartroscopia obtenidos mediante RM, que arroja una mejoría en el desplazamiento discal en sólo el $27 \%$ de las articulaciones, tratándose la mayoría de ellos de estadios tempranos de la enfermedad.

Basándonos en la comparación de los resultados obtenidos con la lisis y lavado y otras técnicas artroscópicas recogidas en la bibliografía, se puede argumentar la falta de diferencia en los resultados clínicos entre ellas. Así, Miyamoto, ${ }^{12}$ tras aplicar lisis y lavado en 41 articulaciones con daño interno articular en estadio III de Wilkes, frente a lisis

\section{Discussion}

Since Onishis performed an arthroscopy for the first time in Japan in 1975, this technique has been widely developed in the United States and Europe, its success being published in the literature.

In 1990, in a prospective study of 76 articulations treated by lysis and lavage, Perrott et al. ${ }^{9}$ obtained an increase of the mean MIO of $29.91 \pm 10.1 \mathrm{~mm}$ to 37.93 $\pm 10.52 \mathrm{~mm}$, this being statistically significant, as well as decrease of pain measured with the analogue and categorized visual scale (none, middle, moderate and severe) with a mean follow-up of $12.56 \pm 2.87$ months for only 34 articulations of the total. The comparison of the postarthroscopy MRI (between 1 and 17 months) with the previous images did not show differences in regards to disk position in 25 of the 29 articulations studied. In 1991, Clark et al. ${ }^{10}$ performed a prospective two year postarthroscopy follow-up study of 22 articulations (18 subjects) with internal derangement of the TMJ, obtaining a $57 \%$ decrease in pain, and an increase in the MIO mean of $13 \mathrm{~mm}$, both being statistically significant. In 1996, Murakami et al. 7 published a study with a mean followup of 50 months (from 3 to 5 years) after arthroscopic surgery of 24 TM/s (women) with internal joint derangement in Wilkes stage $V$, performing capsular anterolateral release by electrocauterization, assessing the MIO, pain, and articular dysfunction with a pre-and postoperatory VAS as well as the presence of cracking sounds to the aus- 
y lavado más liberación capsular anterolateral en 73 articulaciones en el mismo estadio, concluye que la única diferencia estadísticamente significativa es la menor apertura oral obtenida en el primer grupo al mes de evolución; diferencia que se iguala al cabo de 12 meses de seguimiento. Por tanto, la gran similitud de los resultados apoyaría el tratamiento con lavado y lisis artroscópica frente a otras técnicas, ya que la artroscopia es una procedimiento mínimamente invasivo, causa menos trauma quirúrgico y se asocia a menor morbilidad, siendo más rápida la recuperación del paciente. No obstante se hacen necesarios ensayos clínicos controlados para comparar la efectividad de las distintas técnicas artroscópicas, así como estudios de concordancia clínico-patológicos en la patología de la ATM.

\section{Conclusiones}

1. La cirugía artroscópica (lisis y lavado del espacio superior con manipulación mandibular) es una técnica útil y efectiva, para el SDTM, tanto en los estadios tempranos como tardíos de la enfermedad.

2. Mejora significativamente el dolor, MAO, protrusión, laterotrusión y los ruidos articulares. Permite a los pacientes realizar una dieta normal.

3. Se demuestra que la mejoría de la apertura interincisal con la lisis y lavado artrocópico es mayor en los estadios tempranos del SDTM.

4. Es una técnica mínimamente invasiva y mórbida.

\section{Bibliografía}

1. Pericot J, Biosca MJ. Actualidades Clínico-Terapeúticas en Cirugía Maxilofacial. Barcelona. Uriach, 1997.

2. Goss AN. Toward an international consensus on temporomandibular joint surgery. Int J Oral Maxillofac Surg 1993;22:78-81.

3. Franklin M. The role of temporomandibular joint surgery in the treatment of patients with internal derangement. Oral Surg Oral Med Oral Pathol Oral Radiol Endod 1997;83:150-5.

4. Boering G. De Bont LGM. Stegenga. Guidelines for diagnosis and management of temporomandibular disorders. Groningen: American Society for Temporomandibular Joint Surgeons. 1990.

5. De Leew R, Boering G, y cols. TMJ articular disc position and configuration 30 years after initial diagnosis of internal derangement. J Oral Maxillofac Surg 1995;53:234-41.

6. Wilkes $\mathrm{CH}$. Internal derangement of the temporomandibular joint. Pathological variation. Arch Otolaryngol Head Neck Surg 1989;115:469.

7. Murakami Kl, Moriya Y, Goto K, Segami N. Four-year follow-up study of temporomandibular joint arthroscopic surgery for advanced stage internal Derangements. J Oral Maxillofac Surg 1996;54:285-90.

8. Ohnishi M. Arthroscopy of the temporomandibular joint. / Jpn Stomat 1975;42: 207-12.

9. Perrott DH, Alborzi A, Kaban LB, y cols. A prospective evaluation of the effectivenes of temporomandibular joint arthroscopy. J Oral Maxillofac Surg 1990;48: 1029-32.

10. Clark GT, Moody DG, Sanders B. Arthroscopic treatment of temporomandibular joint locking resulting from disc derangement. J Oral Maxillofac Surg 1991;49:157-64. cultation and palpation. They obtained statistically significant differences between the mean pre- and postsurgical values, with a MIO mean of 33 to 38.8 respectively, and decrease of pain from 7 to 1.3.

In our study, we assess the clinical-radiological results after the administration of lysis and lavage by arthroscopy in patients diagnosed of TMJD. Being aware of the disadvantages of a sample size that is not large, we performed a prospective study with a mean follow-up of 27 months (range: 12 to 63 months) without data losses during it. As in the previously mentioned studies, we demonstrated the utility of the arthroscopy as a treatment of internal joint derangement of the TMJ by lysis and lavage, after obtaining a statistically significant improvement in pain, MIO, protrusion, right and left laterotrusion, and crackling sounds in $80 \%, 100 \%, 92 \%, 84 \%, 92 \%$ and $63 \%$ of the patients respectively, $77 \%$ of the patients being able to carry out a normal diet and only 38\% requiring postarthroscopy myorelaxation splint. In addition, this improvement in the variables occurs in both the early as well as advanced stages of $T M J D$, it being maintained during the follow-up period. However, the improvement of the MIO is significantly greater when the technique is applied in the early stages of the disease.

We coincide with the results presented by Moses ${ }^{11}$ et al. in a prospective study of 152 articulations with anterior disk displacement treated by arthroscopic lysis and lavage, with a mean follow-up of 19 months, that obtains an improvement in disk mobility in $80 \%$ of the patients, although with persistence of anterior disk displacement in 92\% of them detected by the MRI. In our study, we also carried out an analysis of the pre-and post-arthroscopy X-ray findings obtained by MRI, that show an improvement in the meniscus displacement in only $27 \%$ of the articulations, most of them being early stages of the disease.

Based on the comparison of the results obtained with lysis and lavage and other arthroscopic techniques found in the literature, the lack of difference in the clinical results between them can be stated. Thus, Miyamoto,12 after applying lysis and lavage in 41 articulations with internal articular derangement in Wilkes stage III, compared to lysis and lavage plus anterolateral capsular release in 73 articulations in the same stage, concluded that the only statistically significant difference is the lower oral opening obtained in the first group at one month of evolution; a difference that becomes equaled at 12 months of followup. Thus, the great similarity of the results would support treatment with arthroscopic lavage and lysis compared to other techniques, since the arthroscopy is a minimally invasive procedure, causes less surgical trauma and is associated to lower morbidity, the recovery of the patient being faster. However, controlled clinical trials are necessary to compare the effectiveness of the different arthroscopic techniques as well as clinical-pathological concordance studies in the pathology of TMJ. 
11. Moses IJ, Sartoris D, Glass R, y cols. The effects of arthroscopic lysis and lavage of the superior joint space on TMJ disc position and mobility. J Oral Maxillofac Surg 1989;47:674-8.

12. Miyamoto $H$, Sakashita $H$, Miyata M, Goss AN. Arthoroscopic surgery of the temporomandibular joint: comparison of two successful techniques. $\mathrm{Br}$ / Oral Maxillofac Surg 1999;37:397-400.

13. Dean White R. Arthorscopic lysis and lavage as the preferred treatment for internal derangement of the temporomandibular joint. J Oral Maxillofac Surg 2001;59: 313-6.

14. Mosby EL. Effects of temporomandibular joint arthroscopy. A retrospective study. J Oral Maxillofac Surg 1993;51:17-21.

\section{Conclusions}

1. Arthroscopic surgery (lysis and lavage of the upper space with mandibular manipulation) is a useful and effective technique for TMID, both in early as well as late stages of the disease.

2. Pain, MIO, protrusion, laterotrusion and articular noises significantly improve. It makes it possible for the patient to have a normal diet.

3. It is shown that the improvement of the interincisal opening with arthroscopic lysis and lavage is greater in the early stages of TMJD.

4. It is a minimally invasive and morbid technique. 


\title{
La artroscopia en el daño interno de la ATM: resultados clínicos de un estudio prospectivo
}

\author{
Arthroscopy for the internal derangement of TMJ: clinical outcome from a prospective evaluation
}

En este estudio prospectivo, los autores demuestran la eficacia de la lisis y lavado en el tratamiento quirúrgico de lo que denominamos disfunción de la articulación temporomandibular, cuyo inicio evolutivo lo situamos en el estadio Wilkes I y en estadios finales lo situamos en el Wilkes $\mathrm{V}$.

Numerosos estudios han demostrado en los últimos 15-20 años la eficacia del tratamiento quirúrgico mediante artroscopia y en concreto realizando lisis y lavado. Sigue siendo interesante, desde mi punto de vista, la realización prospectiva de este trabajo, aunque como los autores reconocen, el tamaño de la muestra es escaso y sobre todo, en relación con los estadios III y IV que son los más habituales en la patología que indicamos el tratamiento quirúrgico.

El diseño del estudio se ha realizado con corrección, aunque habría que insistir en los falsos positivos que plantea la resonancia magnética en relación con la perforación discal. Si bien no es un dato que modifique la intención del estudio, nos parece que deberían evaluarse con más seguridad otros hallazgos de la resonancia magnética para la inclusión en los estadios de Wilkes, según los criterios de imagen.

Es importante insistir en las dos razones que consideramos más frecuentes en la etiología de la disfunción (el micro y el macrotrauma). En nuestro protocolo debemos claramente incluir a los primeros como microtrauma: los antecedentes de bruxismo y graves alteraciones oclusales, y a los segundos, macrotrauma, la relación directa que existiese con un traumatismo articular.

La evolución de los tratamientos quirúrgicos, cada vez en la línea de técnicas mínimamente invasivas, obliga a los cirujanos maxilofaciales a plantearnos la artroscopia como una técnica quirúrgica cuyo manejo es obligado en la patología de la disfunción articular.

También debemos, los cirujanos maxilofaciales que realizamos tratamientos de la patología articular, no olvidarnos nunca del concurso de otros especialistas en este tratamiento: los fisioterapeutas, ortodoncistas y protodoncistas, estando obligados a conocer las posibilidades terapéuticas que manejan estos especialistas.

\section{J.L. Gil Díez Usandizaga} Jefe de Sección Servicio de Cirugía Oral y Maxilofacial Hospital de la Princesa, Madrid, España
In this prospective study, the authors show the efficacy of lysis and lavage in surgical treatment of that called temporomandibular joint dysfunction, whose evolutive onset is located in Wilkes stage I and in Wilkes V in the final stages.

In the last 15-20 years, our studies have demonstrated the efficacy of surgical treatment by arthroscopy and, specifically, performing lysis and lavage. From my point of view the prospective performance of this study is still interesting, although, as the authors admit, the sample size is limited and above all, in relationship with stages III and $I V$, which are the most common in the disease in which the surgical treatment is indicated.

The study design has been correctly performed, although the false positives established by the magnetic resonance in relationship with disk perforation must be stressed. Although it is not data that change the intention of the study, we feel that other magnetic resonance findings should be assessed with more security for inclusion in the Wilkes' stages, according to imaging criteria.

It is important to stress the two reasons that we consider most frequent in the dysfunction etiology (micro- and macrotrauma). In our protocol, we should clearly include the first as microtrauma: the background of bruxism and serious occlusal disorders, and in the second, macrotrauma, the direct relationship that exists with joint traumatism.

The evolution of the surgical treatments, whenever it is within minimally invasive techniques, makes it necessary for the maxillofacial surgeons to consider the arthroscopy as a surgical technique whose management is required in joint dysfunction disease.

In additions those maxillofacial surgeons who treat joint diseases should not ever forget the concurrence of other specialists in this treatment: physiotherapists, orthodontists and prostodontists, and they must know the therapeutic possibilities performed by these specialists. 